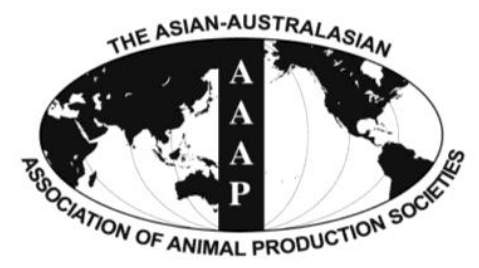

Asian-Aust. J. Anim. Sci.

Vol. 25, No. 11 : 1634-1640 November 2012

http://dx.doi.org/10.5713/ajas.2012.12296

www.ajas.info

pISSN 1011-2367 elSSN 1976-5517

\title{
Comparison of Pork Quality and Sensory Characteristics for Antibiotic Free Yorkshire Crossbreds Raised in Hoop Houses
}

\author{
N. Whitley, D. Hanson ${ }^{1}$, W. Morrow ${ }^{2}$, M. T. See ${ }^{2}$ and S.-H. Oh* \\ Department of Animal Sciences, North Carolina Agricultural and Technical State University, USA
}

\begin{abstract}
The objective of this study was to compare pork characteristics and to determine consumer acceptability of pork chops from antibiotic free Yorkshire crossbreds sired by Berkshire (BY), Large Black (LBY), Tamworth (TY) or Yorkshire (YY) boars and reared in hoop houses. The experiments were conducted at the North Carolina Agricultural and Technical State University (NCA\&TSU) Farm in Greensboro, NC and the Cherry Research Station Center for Environmental Farming Systems (CEFS) Alternative Swine Unit in Goldsboro, NC (source of antibiotic free Yorkshire sows used at both places). Twenty-four sows were artificially inseminated at each location in each of three trials. Litters were weaned at 4 wks old, and reared within deep-bedded outdoor hoop houses. To compare pork characteristics, 104 randomly selected animals were harvested at a USDA-inspected abattoir at approximately $200 \mathrm{~d}$ of age. Variables measured included $\mathrm{pH}$, color score, $\mathrm{L}^{*}, \mathrm{a}^{*}, \mathrm{~b}^{*}$, marbling score, drip loss, hot carcass weight, backfat thickness (BF), loin muscle area (LMA), and slice shear force. Sensory panel tests were also conducted at two time periods. The data was analyzed with GLM in SAS 9.01 including location, trial, and sire breed as fixed effects. Backfat thickness, LMA, color score and a* were different among breeding groups ( $\mathrm{p}<0.05$ ). The LBY pigs had thicker backfat and smaller LMA than the other breed types. The TY and YY had less backfat than all other breed groups. Color score was lower for YY than BY and LBY but intermediate for TY. The a* was lower for TY than other breeds except LBY which was intermediate. For one sensory panel test, YY pork was more preferred overall as well as for juiciness and texture compared to BY and LBY ( $<<0.05)$, but no impact of breed type was noted for the other test, with values similar for BY, LBY, TY and YY pork. This information may help small farmers make decisions about breed types to use for outdoor production. (Key Words: Outdoor, Antibiotic-Free, Yorkshire, Crossbred, Pork)
\end{abstract}

\section{INTRODUCTION}

In recent years, food safety issues and human health concerns have been raised regarding excessive medication of confinement-raised animals resulting in possible antibiotic resistance diseases. In addition, animal welfare has long been a concern for pork producers and, more recently, for consumers. Conventional confinement pork production systems are often criticized for animal welfare and environmental impacts (Ngapo et al., 2003; Lebret et al., 2006), and consumer preference is generally higher for organically produced animal products and/or for meat produced not intensively (Bee et al., 2004; Yiridoe et al.,

\footnotetext{
* Corresponding Author: S.-H. Oh. Tel: +1-336-334-7672, Fax: +1-336-334-7288, E-mail: soh@ncat.edu

${ }^{1}$ Department of Food Science, North Carolina State University, USA.

${ }^{2}$ Department of Animal Science, North Carolina State University, USA.

Submitted May 30, 2012; Accepted Aug. 11, 2012; Revised Aug. 28, 2012
}

2005). In response, new markets have emerged for animal compassionate and alternative pork production. Wholesale buyers are willing to offer United States growers higher sales prices to supply this demand, which indicates an important opportunity for small-scale, limited resource farmers.

There has been resurgence in interest in outdoor pig production recently (Thornton, 1990; Honeyman, 2005), and concern that the productivity of sows and pigs raised outdoors would suffer has declined (Kleinbeck and McGlone, 1999). One of the concerns with outdoor systems is that there is less control over the production environment which may adversely affect animal performance, especially in regions with hot and humid climates. Alternative production systems, including pasture-based huts and deepbedded hoop barns have the potential to address animal welfare, food safety and some environmental concerns as well as provide new opportunities for small, limited resource farmers because of the lower capital cost (Gentry et al., 2002; Honeyman and Harmon, 2003). 
An important question that needs to be addressed is which genotypes (breeds) are best fitted to the outdoor system (Kleinbeck and McGlone, 1999). There is anecdotal evidence to suggest that some breeds of pigs perform "better" in an outdoor system than others. For example, breeds such as Tamworth (McPhee, 1931; Winters et al., 1943; Gegner, 2001) and Large Black (ALBC, 2012) have been promoted as alternative breeds for outdoor production. Also, the Berkshire breed is known to have superior meat quality when raised in confined systems (Suzuki et al., 2003; Aziz, 2004), and might also be a good candidate for alternative production systems. It has been reported that about 28,000 dams are bred in Japan, and the retail price of purebred Berkshires is $50 \%$ more expensive than regular finishing pigs (Suzuki et al., 2003). However, there are few scientific studies regarding which breeds or lines of pigs actually excel in outdoor production facilities. Therefore, the objective of this study was to compare pork characteristics and determine consumer acceptability of pork chops from antibiotic free Yorkshire crossbreds sired by Berkshire, Large Black, Tamworth or Yorkshire boars and reared in deep-bedded outdoor hoop houses.

\section{MATERIAL AND METHODS}

\section{Crossbreds and environments}

The experiments were conducted at the North Carolina Department of Agriculture and Consumer Services Cherry Research Station, Center for Environmental Farming Systems (CEFS) Alternative Swine Unit, and at the university farm swine unit at North Carolina Agricultural and Technical State University (NCA\&TSU). The CEFS unit is located in Goldsboro, NC (latitude $+35^{\circ} 23^{\prime} 26.82^{\prime \prime}$, longitude $\left.-78^{\circ} 1^{\prime} 43.76^{\prime \prime}\right)$ and the NCA\&TSU farm is in Greensboro, NC (latitude $+36^{\circ} 4^{\prime} 16.63^{\prime \prime}$, longitude $-79^{\circ} 43^{\prime}$ $33.02^{\prime \prime}$. Both locations feature a humid subtropical climate with subtropical summer temperatures and mild winters, and an average annual precipitation of approximately 110 $\mathrm{cm}$.

The CEFS unit has been raising antibiotic-free Yorkshire sows for more than $10 \mathrm{yrs}$, and animals used in both locations came from this site. Twenty-four gilts selected randomly were artificially bred at each location in each of three trials after feeding Matrix ${ }^{\circledR}$ for estrus synchronization as per the manufacturer's directions. Semen from Berkshire (BY), Large Black (LBY), Tamworth (TY) and Yorkshire (YY, control animals) boars was used with semen from at least 3 randomly selected boars per breed mixed to remove specific boar effects. Table 1 indicates the number of animals in each trial for each location. Trials taking place in Fall 2009, Spring 2010, and Fall 2010 were designated as Trial 1, 2, and 3, respectively.
Table 1. Number of pigs used in pork quality characteristic studies and sensory panel tests by location and trial*

\begin{tabular}{|c|c|c|c|c|c|c|}
\hline \multirow{2}{*}{$\begin{array}{c}\text { Breed } \\
\text { type }\end{array}$} & \multicolumn{3}{|c|}{ NCA\&TSU } & \multicolumn{3}{|c|}{ CEFS } \\
\hline & Trial $1^{\mathrm{a}}$ & Trial $2^{b}$ & 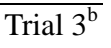 & Trail $1^{\mathrm{a}}$ & Trial $2^{\mathrm{b}}$ & 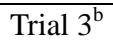 \\
\hline$\overline{\mathrm{BY}}$ & 10 & 6 & 5 & 7 & - & 7 \\
\hline LBY & 10 & 6 & - & 7 & - & - \\
\hline TY & - & - & 5 & - & - & 7 \\
\hline YY & 10 & 5 & 5 & 7 & - & 7 \\
\hline Total & 30 & 17 & 15 & 21 & - & 21 \\
\hline
\end{tabular}

* Locations were North Carolina A\&T State University (NCA\&TSU) and the Center for Environmental Farming Systems (CEFS). Breed types were Berkshire $\times$ Yorkshire (BY), Large Black $\times$ Yorkshire, Tamworth $\times$ Yorkshire (TY) and Yorkshire $\times$ Yorkshire (YY).

${ }^{\text {a }}$ Sensory test $1 .{ }^{\mathrm{b}}$ Sensory test 2 .

Sows farrowed in hoop structures and pigs were castrated within a week then weaned when the youngest litter was 4 wks old. Weaned pigs were reared within deepbedded hoop houses until harvest with ad libitum NRC based diets balanced for stage of production and free choice fresh water. The deep bedding, generally straw, corn stalks, or hay, was spread approximately 35 to $45 \mathrm{~cm}$ thick as needed to provide a comfortable environment for the animals which allowed rooting and other natural behaviors.

\section{Carcass data collection}

Carcass characteristics were measured using 104 randomly selected animals that were harvested at a USDAinspected abattoir at approximately $200 \mathrm{~d}$ of age. At harvest, hot carcass weight (including the head) was collected prior to refrigeration. After refrigeration for $24 \mathrm{~h}$, carcass collection procedures followed NPPC guidelines (NPPC, 2000); back fat (BF) depth at 1st rib, 10th rib and last lumbar were collected as well as longissimus muscle area (LMA). The longissimus dorsi (LD) was collected from the right side loins. All the boneless loins were packed in ice and transported approximately one hour to the NCSU Processed Meat Laboratory for storage at $2{ }^{\circ} \mathrm{C}$ until further analysis.

\section{Pork quality measurements}

Chops were cut $2.54-\mathrm{cm}$ thick from each of the LD samples. Marbling score (1 to 10) and color score (1 to 6) was recorded (NPPC, 2000) and a LD chop was used to determine drip loss by placing a $100 \mathrm{~g}$ sample on a hook and hanging it in a plastic bag at $2{ }^{\circ} \mathrm{C}$ for $48 \mathrm{~h}$. To determine ultimate $\mathrm{pH}$, a chop sample was homogenized with a variable speed laboratory blender (Waring, New Hartford, CT, USA) and deionized water added to a final dilution of 1:10. Samples were blended for $20 \mathrm{~s}$ and $\mathrm{pH}$ was determined using an Accumet Excel XL15 pH meter with glass tip probe (Thermo Fisher Scientific, Waltham, MA, USA). Color of the LD was objectively evaluated by Minolta L*, a*, and $\mathrm{b}^{*}$ measurements using a Minolta 
Chroma Meter (CR-200, Ramsey, New Jersey, USA) using D65 illuminant and calibrated with a standard white plate. Minolta values were reported as the average color values from measurements conducted at three positions on the surface of each chop after a minimum of $20 \mathrm{~min}$ of the initial cut. Slice shear force was conducted to estimate tenderness (Shackelford et al., 2004).

\section{Pork quality characteristics and sensory panel tests}

Pork quality and sensory panel tests were conducted at North Carolina State University (Table 2). The first sensory panel test was held with 109 consumers using pork from the pigs in Trial 1, and the second test was with 107 consumers using pork from the pigs in Trial 2 and 3. Consumers were recruited through a screener launched to an on-line database maintained by the Sensory Service Center with over 3,000 members. Consumers were compensated with a five dollar grocery store gift card for their participation. Consumers had to be at least 19 yrs old, no older than 59 yrs old, and consume pork at least a few times per year.

Chops for each test were thawed at $4{ }^{\circ} \mathrm{C}$ and cooked on an Impinger conveyor oven set at $200^{\circ} \mathrm{C}$. After being wrapped and labeled, chops were placed in a warming cabinet set to $75^{\circ} \mathrm{C}$. Samples were replaced with fresh samples after $30 \mathrm{~min}$. Samples were cut for consumers using a cutting mold, resulting in a $2 \times 2 \times 1 \mathrm{~cm}^{3}$ sample of pork. Samples were placed in labeled containers and presented to consumers with a fork, napkin, and cup of deionized water.

When consumers arrived for the taste test, they were instructed they would taste four samples of pork chops and would have to rank them in order of preference at the end of

Table 2. Demographic information and consumer consumption characteristics for sensory tests on pork chops from four different breed type pigs raised in an outdoor hoop barn

\begin{tabular}{|c|c|c|c|}
\hline & & Test $1(\mathrm{n}=109 ; \%)$ & Test $2(\mathrm{n}=107 ; \%)$ \\
\hline \multirow[t]{2}{*}{ Gender } & Male & 38.5 & 27.1 \\
\hline & Female & 61.5 & 72.9 \\
\hline \multirow[t]{8}{*}{ Age } & 18 years old or younger & 0.0 & 0.0 \\
\hline & 19 to $25 \mathrm{yrs}$ old & 25.7 & 16.8 \\
\hline & 26 to 35 yrs old & 35.8 & 28.0 \\
\hline & 36 to 45 yrs old & 13.7 & 21.5 \\
\hline & 46 to 54 yrs old & 15.6 & 25.2 \\
\hline & 55 to 59 yrs old & 6.4 & 8.4 \\
\hline & 60 to 70 yrs old & 2.8 & 0.0 \\
\hline & 71 yrs old and older & 0.0 & 0.0 \\
\hline \multirow[t]{2}{*}{ Primary shopper } & Yes & 92.7 & 94.4 \\
\hline & No & 7.3 & 5.6 \\
\hline \multirow[t]{3}{*}{ Marital Status } & Married & 47.7 & 46.7 \\
\hline & Single & 52.3 & 48.6 \\
\hline & Other & 0.0 & 4.7 \\
\hline \multirow[t]{6}{*}{ How often do you consume pork? } & Never & 0.0 & 0.0 \\
\hline & A few times per yr & 4.6 & 5.6 \\
\hline & At least once per month & 22.9 & 15.0 \\
\hline & At least 2 to 3 times per month & 40.4 & 33.6 \\
\hline & At least once per wk & 19.3 & 23.4 \\
\hline & Two or more times per wk & 12.8 & 22.4 \\
\hline \multirow{11}{*}{$\begin{array}{l}\text { What factors influence } \\
\text { your purchase of pork?* }\end{array}$} & Cost & 79.9 & 80.4 \\
\hline & Convenience & 45.0 & 50.5 \\
\hline & Flavor & 81.7 & 87.9 \\
\hline & Tenderness & 69.7 & 80.4 \\
\hline & Health/nutritional value & 40.4 & 50.5 \\
\hline & Availability & 41.3 & 48.6 \\
\hline & Appearance & 57.8 & 70.1 \\
\hline & Natural label claim & 13.8 & 18.7 \\
\hline & Organically raised & 8.3 & 13.1 \\
\hline & Packaging & 16.5 & 24.3 \\
\hline & Other (specify)** & 1.8 & 2.8 \\
\hline
\end{tabular}

\footnotetext{
* More than one answer was allowed, so total percentage will be greater than 100 .

** Consumers who marked "other" as an important factor responded: "cut of pork", "marbling", "previous experience with the brand", and "ethnic use of pork meat for special celebrations".
} 
the test. Consumers answered demographic questions identical to what was asked on the recruitment screener. Consumers were then presented with their first sample and asked to indicate their overall liking on a 9 point Hedonic scale for which $1=$ dislike extremely and $9=$ like extremely. Consumers then indicated their overall flavor, juiciness and tenderness liking on the 9 point Hedonic scale. After all four samples were tasted, consumers ranked the samples in order of preference in which $1=$ most preferred and $4=$ least preferred.

\section{Data analyses}

For pork characteristics, location, trial, and sire were included in the statistical model as fixed effects using PROC GLM in SAS 9.2. Hot carcass weight was also included as a covariate in the model. For sensory panel data, scores were evaluated by ANOVA using SAS 9.2. Location, sire and interaction between them were included in the model as fixed effects. Overall ranking was evaluated by Friedman's Rank Sum using XLSTAT. All statistics were calculated to $95 \%$ confidence.

\section{RESULTS AND DISCUSSION}

\section{Pork quality characteristics}

Pork quality is an important factor for niche pork markets (Lammers et al., 2007). However, few studies have compared different breed types in alternative production systems. For the current study, the impact of location, trial and breed type on measured pork quality characteristics are noted in Table 3. Least square means and standard errors for each characteristic by location, trial and breed type are presented in Table 4. There was no effect of breed on hot
Table 3. Significance of fixed effects on variables of pork quality characteristics of four different breed types raised in an outdoor hoop barn

\begin{tabular}{lccc}
\hline Variable & \multicolumn{3}{c}{ Effects } \\
\cline { 2 - 4 } Measured & Location & Trial & Breed type \\
\hline $\mathrm{pH}$ & $* *$ & $* *$ & $\mathrm{NS}$ \\
Color score & $\mathrm{NS}$ & $\mathrm{NS}$ & $*$ \\
$\mathrm{~L}^{*}$ & $* *$ & $* *$ & $\mathrm{NS}$ \\
$\mathrm{a}^{*}$ & $* *$ & $* *$ & $*$ \\
$\mathrm{~b}^{*}$ & $* *$ & $\mathrm{NS}$ & $\mathrm{NS}$ \\
Marbling score & $* *$ & $* *$ & $\mathrm{NS}$ \\
LLBF $(\mathrm{cm})$ & $\mathrm{NS}$ & $* *$ & $* *$ \\
BF10 $(\mathrm{cm})$ & $\mathrm{NS}$ & $*$ & $* *$ \\
BF1 $(\mathrm{cm})$ & $\mathrm{NS}$ & $*$ & $* *$ \\
LMA $\left.(\mathrm{cm})^{2}\right)$ & $\mathrm{NS}$ & $* *$ & $* *$ \\
Drip loss & $\mathrm{NS}$ & $\mathrm{NS}$ & $\mathrm{NS}$ \\
Slice shear force & $* *$ & $* *$ & $\mathrm{NS}$ \\
\hline
\end{tabular}

$* \mathrm{p}<0.05 ; * * \mathrm{p}<0.01$.

NS $=$ Not significant

Locations were North Carolina A\&T State University (NCA\&TSU) and the Center for Environmental Farming Systems (CEFS). Breed types were Berkshire $\times$ Yorkshire (BY), Large Black $\times$ Yorkshire, Tamworth $\times$ Yorkshire (TY) and Yorkshire $\times$ Yorkshire (YY).

Abbreviated variables include last lumber backfat (LLBF), 10th rib backfat (BF10), 1st rib backfat (BF1) and loin muscle area (LMA); L* indicates muscle lightness, $\mathrm{a}^{*}$ is a measure of muscle redness and $\mathrm{b}^{*}$ is a measure of muscle yellowness.

carcass weight (which was used as a covariable in the statistical analyses), and the overall average for all animals was $87.7 \pm 11.8 \mathrm{~kg}$.

\section{pH}

A higher $\mathrm{pH}$ results in less drip loss and also increases dark color (most noticeable and a $\mathrm{pH}$ greater than 5.7). In

Table 4. Least square means and standard errors of each characteristic by location, trial, and breed type for pigs raised in an outdoor hoop barn

\begin{tabular}{|c|c|c|c|c|c|c|c|c|c|}
\hline \multirow{2}{*}{$\begin{array}{l}\text { Variables } \\
\text { Measured }\end{array}$} & \multicolumn{2}{|c|}{ Location } & \multicolumn{3}{|c|}{ Trial } & \multicolumn{4}{|c|}{ Breed type } \\
\hline & NCAT & CEFS & 1 & 2 & 3 & $\mathrm{BY}$ & LBY & TY & YY \\
\hline$\overline{\mathrm{pH}}$ & $5.54 \pm 0.02^{\mathrm{a}}$ & $5.73 \pm 0.05^{\mathrm{b}}$ & $5.80 \pm 0.05^{\mathrm{a}}$ & $5.76 \pm 0.05^{\mathrm{a}}$ & $5.35 \pm 0.03^{\mathrm{b}}$ & $5.63 \pm 0.04^{\mathrm{a}}$ & $5.71 \pm 0.05^{\mathrm{a}}$ & $5.62 \pm 0.06^{\mathrm{a}}$ & $5.59 \pm 0.04^{\mathrm{a}}$ \\
\hline Colo & $52 \pm 0.07^{\mathrm{a}}$ & $3.34 \pm 0.14^{\mathrm{a}}$ & $44 \pm 0.12^{\mathrm{a}}$ & $5 \pm 0.14^{\mathrm{a}}$ & $3.51 \pm 0.09^{\mathrm{a}}$ & $.55 \pm 0.10^{\mathrm{a}}$ & $3.63 \pm 0.13^{\mathrm{a}}$ & $3.27 \pm 1.66^{\mathrm{ab}}$ & $3.29 \pm 0.10^{\mathrm{b}}$ \\
\hline $\mathrm{L}^{*}$ & $46.17 \pm 0.30^{\mathrm{a}}$ & $52.85 \pm 0.63^{\mathrm{b}}$ & $47.63 \pm 0.56^{\mathrm{a}}$ & $50.60 \pm 0.66^{\mathrm{b}}$ & $50.29 \pm 0.40^{\mathrm{b}}$ & $49.08 \pm 0.46^{\mathrm{a}}$ & $49.09 \pm 0.60^{\mathrm{a}}$ & $50.04 \pm 0.76^{\mathrm{a}}$ & $49.81 \pm 0.47^{\mathrm{a}}$ \\
\hline$a^{*}$ & $.41 \pm 0.19^{\mathrm{a}}$ & $9.00 \pm 0.41^{\mathrm{b}}$ & $8.81 \pm 0.36^{\mathrm{a}}$ & $7.18 \pm 0.42^{\mathrm{b}}$ & $8.61 \pm 0.26^{\mathrm{a}}$ & $8.63 \pm 0.30^{\mathrm{a}}$ & $8.49 \pm 0.39^{\mathrm{ab}}$ & $7.38 \pm 0.49^{\mathrm{b}}$ & $8.32 \pm 0.30^{\mathrm{a}}$ \\
\hline$b^{*}$ & $10 \pm 0.13^{\mathrm{a}}$ & $7.33 \pm 0.28^{b}$ & $6.34 \pm 0.25^{\mathrm{a}}$ & $5.83 \pm 0.29^{\mathrm{a}}$ & $6.47 \pm 0.18^{\mathrm{a}}$ & $6.38 \pm 0.21^{\mathrm{a}}$ & $6.21 \pm 0.27^{\mathrm{a}}$ & $5.90 \pm 0.34^{\mathrm{a}}$ & $6.37 \pm 0.21^{\mathrm{a}}$ \\
\hline Mar & $1.63 \pm 0.07^{\mathrm{a}}$ & $0.86 \pm 0.14^{b}$ & $43 \pm 0.12^{\mathrm{a}}$ & $0.70 \pm 0.15^{\mathrm{b}}$ & $1.61 \pm 0.09^{\mathrm{a}}$ & $1.33 \pm 0.10^{\mathrm{a}}$ & $1.32 \pm 0.13^{\mathrm{a}}$ & $1.16 \pm 0.17^{\mathrm{a}}$ & $1.17 \pm 0.10^{\mathrm{a}}$ \\
\hline LLBF & $2.55 \pm 0.10^{\mathrm{a}}$ & $2.79 \pm 0.22^{\mathrm{a}}$ & $3.41 \pm 0.19^{\mathrm{a}}$ & $2.14 \pm 0.22^{b}$ & $2.45 \pm 0.14^{\mathrm{b}}$ & $2.75 \pm 0.16^{\mathrm{a}}$ & $3.48 \pm 0.21^{\mathrm{b}}$ & $2.10 \pm 0.26^{\mathrm{c}}$ & $2.36 \pm 0.16^{\mathrm{c}}$ \\
\hline BF10 & $2.57 \pm 0.10^{\mathrm{a}}$ & $2.27 \pm 0.20^{\mathrm{a}}$ & $2.25 \pm 0.18^{\mathrm{a}}$ & $2.17 \pm 0.21^{\mathrm{a}}$ & $2.84 \pm 0.13^{\mathrm{b}}$ & $2.37 \pm 0.15^{\mathrm{a}}$ & $3.42 \pm 0.20^{\mathrm{b}}$ & $1.85 \pm 0.24^{\mathrm{c}}$ & $2.04 \pm 0.15^{\text {ac }}$ \\
\hline BF1 & $3.59 \pm 0.10^{\mathrm{a}}$ & $3.21 \pm 0.21^{\mathrm{a}}$ & $3.59 \pm 0.19^{\mathrm{a}}$ & $2.99 \pm 0.22^{\mathrm{b}}$ & $3.66 \pm 0.13^{\mathrm{a}}$ & $3.36 \pm 0.16^{\mathrm{a}}$ & $4.05 \pm 0.20^{\mathrm{b}}$ & $3.17 \pm 0.25^{\mathrm{a}}$ & $3.07 \pm 0.16^{\mathrm{a}}$ \\
\hline $\operatorname{LMA}\left(\mathrm{cm}^{2}\right)$ & $38.51 \pm 0.91^{\mathrm{a}}$ & $37.57 \pm 1.93^{\mathrm{a}}$ & $42.87 \pm 1.70^{\mathrm{a}}$ & $35.96 \pm 1.99^{\mathrm{b}}$ & $35.29 \pm 1.21^{\mathrm{b}}$ & $39.38 \pm 1.40^{\mathrm{a}}$ & $33.38 \pm 1.84^{\mathrm{b}}$ & $38.26 \pm 2.30^{\mathrm{ab}}$ & $41.15 \pm 1.43^{\mathrm{a}}$ \\
\hline Drip loss (\%) & $3.38 \pm 0.20^{\mathrm{a}}$ & $3.12 \pm 0.42^{\mathrm{a}}$ & $2.72 \pm 0.37^{\mathrm{a}}$ & $3.27 \pm 0.43^{\mathrm{a}}$ & $4.20 \pm 0.27^{\mathrm{a}}$ & $3.09 \pm 0.31^{\mathrm{a}}$ & $2.67 \pm 0.40^{\mathrm{a}}$ & $3.76 \pm 0.51^{\mathrm{a}}$ & $3.49 \pm 0.31^{\mathrm{a}}$ \\
\hline Slice shear force & $16.76 \pm 0.47^{\mathrm{a}}$ & $19.86 \pm 0.98^{b}$ & $21.68 \pm 0.89^{\mathrm{a}}$ & $17.78 \pm 1.02^{\mathrm{b}}$ & $15.47 \pm 0.62^{\mathrm{b}}$ & $17.72 \pm 0.74^{\mathrm{a}}$ & $18.36 \pm 0.94^{\mathrm{a}}$ & $18.28 \pm 1.18^{\mathrm{a}}$ & $18.88 \pm 0.73^{\mathrm{a}}$ \\
\hline
\end{tabular}

Means with different superscripts among groups within each category differ at $\mathrm{p}<0.05$.

Locations were North Carolina A\&T State University (NCA\&TSU) and the Center for Environmental Farming Systems (CEFS). Breed types were Berkshire $\times$ Yorkshire $(\mathrm{BY})$, Large Black $\times$ Yorkshire, Tamworth $\times$ Yorkshire $(\mathrm{TY})$ and Yorkshire $\times$ Yorkshire $(\mathrm{YY})$.

Abbreviated variables include hot carcass weight (HCW), last lumber backfat (LLBF), 10th rib backfat (BF10), 1st rib backfat (BF1) and loin muscle area (LMA); $\mathrm{L}^{*}$ indicates muscle lightness, $\mathrm{a}^{*}$ is a measure of muscle redness and $\mathrm{b}^{*}$ is a measure of muscle yellowness. 
general, the range of 5.6 to 5.9 would be considered normal in pork (Lammers et al., 2007). In this study, most samples were within the normal range except for Trial 3 which had samples with the lowest $\mathrm{pH}$ for all trials (Table 4). Though breed type did not influence $\mathrm{pH}$, samples from CEFS were higher than those from NCA\&TSU and also had higher measured color indicators $\left(L^{*}, a^{*}, b^{*}\right)$, though $\mathrm{pH}$ values for both locations were within the normal range expected for pork (Table 4). Animals from CEFS were harvested at a younger $(\mathrm{p}<0.05)$ age than those from NCA\&TSU which may have contributed to some location differences.

\section{Color score, $\mathrm{L}^{*}, \mathrm{a}^{*}$ and $\mathbf{b}^{*}$}

Color score was assigned by a trained scientist while $\mathrm{L}^{*}$, $a^{*}$ and $b^{*}$ are instrument-measured values. Lightness $\left(L^{*}\right)$ is measured from 100 , or white, to 0 , or black; red-green, or redness, $\left(a^{*}\right)$ is measured with red being positive and green negative. Yellow-blue, or yellowness, $(b *)$ is measured with yellow being positive and blue negative. Color scores averaged from 3.27 to 3.63 , or an overall reddish pink (Table 4). Although the scientist-estimated color score was lower for YY than BY and LBY samples (TY were intermediate), the instrument measured scores did not support this difference (Table 4). As noted previously, differences for CEFS and NCA\&TSU in measured color values likely relate to the higher $\mathrm{pH}$ noted for CEFS pork. Redness $\left(\mathrm{a}^{*}\right)$ was lower for the Spring trial (the only trial with no animals from CEFS represented), and lightness $\left(L^{*}\right)$ higher for Trial 2 and 3 (Trial 3 was the only one with TY pigs; Table 4).

It has been reported that pigs reared outdoor have darker meat color (Bee et al., 2004), but all of the pigs in this study were raised in a similar manner. Differences in $\mathrm{pH}$ and color have also been noted for different seasons (Judge et al., 1959; Gentry et al., 2002), and although a* was lower for Trial 2, the only trial with animals born in the Fall and harvested in the Spring, this trial was also the only trial for which no animals were harvested from CEFS. Research by others has noted differences in color due to pig breed type (Judge et al., 1959; Skelley and Handlin, 1971; Brewer et al., 2002), but no real important differences were noted for the present study.

\section{Marbling score}

As with color scores, marbling scores were assigned by a trained scientist. The effect of location and trial on marbling score was quite significant, with CEFS pork nearly half that of pork from pigs at NCA\&TSU (perhaps due to the younger harvest age of the animals from CEFS), and Trial 2 scores were half or less than that of Trial 1 and 3 (Table 4). As noted for the present study, there was no effect of breed reported for marbling scores in a study using Duroc, Hampshire and Poland China pigs (Skelley and
Handlin, 1971). In contrast, an earlier study with multiple breeds represented (Landrace, Poland China, Yorkshire, Hampshire, Spotted Poland China and Berkshire) indicated that there were breed effects on marbling score (Judge et al., 1959). Other studies have also noted breed differences for marbling (Wood et al., 1996), including differences for Large White, Meishan type and a synthetic line (Faucitano et al., 2005).

\section{Backfat and loin muscle area (LMA)}

All three measures of backfat (last lumber, 10th rib and 1st rib) were higher for LBY than all other breed types (Table 4), which was not surprising based on visual appraisal of phenotype and the fact that the breed was traditionally known as a bacon-type breed. The TY pigs had generally lower backfat than all but YY pigs (Table 4), likely a result of the use of more modern Tamworth genetics for this study and perhaps because Tamworth were the youngest pigs at harvest $(\mathrm{p}<0.05)$, even though harvest body weights were not influenced by location or breed. The effects of trial were not consistent for backfat (LLFT, BF10 and BF1), with Trial 1 highest for LLFT, Trial 2 lowest for BF1 and Trial 3 highest for BF10 (Table 4). The CEFS location was not represented in all trials and the number of LBY and TY pigs differed among trials (Table 1). Because these breed types had higher (LBY) and generally lower (TY) backfat measurements than the other breed types, it could be that the different numbers of those pigs accounted for the differences among trials.

Trial 1 had the greatest overall number of animals represented (Table 1) and had the largest LMA (Table 4). Again, based on visual appraisal of phenotype, it was not surprising that LBY pigs had smaller LMA than all but TY pigs. Several studies have indicated that backfat and LMA can be influenced by breed (Skelley and Handlin, 1971; Lo et al., 1992; Wood et al., 1996; Hiner et al., 2006).

\section{Drip loss and slice shear force}

Lower values of drip loss are better than higher levels. It is said that drip loss should not exceed $2.5 \%$ in general (Lammers et al., 2007). However, drip loss range for the present study was higher than $2.5 \%$. Similarly, Lebret et al. (2006) reported drip losses of $3.3 \%$ and $5.7 \%$ on two and four days after harvest, respectively, in an outdoor study using Large White $\times$ Landrace crossbred pigs. There were no influences of breed type on drip loss in the present study. In contrast, drip loss was influenced by breed in a study in Germany in that Landrace/Pietrain animals with Duroc heritage had lower drip loss than those with Large White heritage (Morlein et al., 2007).

Slice shear force was not influenced by breed type, though differences were noted for location and trial (Table 4). Other studies support the lack of an influence of breed 
Table 5. Test 1 sensory panel results for pork from three different breed type pigs raised in an outdoor hoop barn at two locations

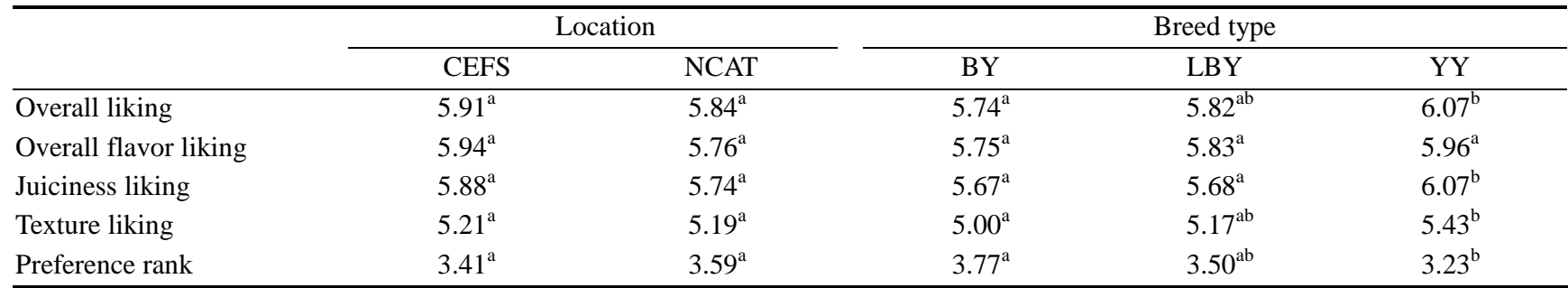

* Data represents 109 consumers. Liking attributes are scored on a 9 point hedonic scale where $1=$ dislike extremely and $9=$ like extremely. Preference Rank is scored on a 4 point scale where $1=$ most preferred and $4=$ least preferred.

Locations were North Carolina A\&T State University (NCA\&TSU) and the Center for Environmental Farming Systems (CEFS). Breed types were Berkshire $\times$ Yorkshire (BY), Large Black $\times$ Yorkshire, Tamworth $\times$ Yorkshire (TY) and Yorkshire $\times$ Yorkshire (YY).

Values with different superscripts in rows differ at $\mathrm{p}<0.05$.

on slice shear force (Skelley and Handlin, 1971; Lo et al., 1992; Edwards et al., 2003).

\section{Sensory panel tests}

Overall liking, overall flavor, juiciness and texture and preference rank were requested in the sensory panel tests. An effect of sire breed for some characteristics was noted for Test 1 (Table 5) but not Test 2 (Table 6). Overall, for the test with only three breeds (BY, LBY and YY), pork from YY was scored as having higher juiciness, texture, and overall liking, and, as would be expected given those scores, YY was also ranked as the most preferred (Table 5). Breed differences were also noted between Large White and Durocs for pork flavor intensity and overall liking scores (higher for Durocs), though tenderness was not different between the two breeds (Wood et al., 1996). Similarly, Duroc pigs had significantly more tender, juicier loins compared to Yorkshire pigs (Hiner et al., 1965). In contrast to the present study, in 1971, Skelley and Handlin reported no differences in flavor, juiciness, tenderness and preference due to breed.

\section{CONCLUSION}

Trends indicate YY had a significant difference in trial 1

Table 6. Test 2 sensory panel results for pork from four different breed type pigs raised in an outdoor hoop barn

\begin{tabular}{lcccc}
\hline & BY & LBY & TY & YY \\
\hline Overall liking & 6.26 & 6.16 & 6.31 & 6.09 \\
Flavor liking & 6.22 & 6.05 & 6.45 & 6.08 \\
Juiciness liking & 6.21 & 6.10 & 6.17 & 6.34 \\
Tenderness liking & 5.57 & 5.59 & 5.70 & 5.59 \\
Preference rank & 2.51 & 2.49 & 2.44 & 2.57 \\
\hline
\end{tabular}

* Data represents 107 consumers. Liking attributes are scored on a 9 point hedonic scale where $1=$ dislike extremely and $9=$ like extremely. Preference Rank is scored on a 4 point scale where $1=$ most preferred and 4 = least preferred. Breed types were Berkshire $\times$ Yorkshire (BY), Large Black $\times$ Yorkshire, Tamworth $\times$ Yorkshire $(\mathrm{TY})$ and Yorkshire $\times$ Yorkshire (YY).

No significant differences were found. for overall acceptability, however the other breeds had mean values that would still be considered acceptable. Although Large Black pigs seemed to have smaller loins and more backfat than the other breed types used, even given differences in harvest age, in general, few differences were noted for carcass traits due solely to breed. In addition, the results of the two sensory tests were different, indicating that more research is needed before firm recommendations can be made as to a particular breed type appropriate for outdoor production systems. Overall, there appears to be little to no difference in meat quality/sensory data regardless of breed or location.

\section{ACKNOWLEDGEMENT}

This material is based in part upon work supported by the USDA SARE of the Southern Region, Project LS08-211, "A multi-disciplinary approach to improve the environmental performance of niche pork production systems and marketability of Heritage swine breeds." This paper is dedicated to the late Mr. Marty Dudley for his support and hard work on this study.

\section{REFERENCES}

ALBC (American Livestock Breed Conservatory). 2012. http://albc-usa.org/cpl/largeblack.html Accessed April 7, 2012.

Aziz, N. 2004. Manipulating pork quality through production and pre-slaughter handling. Advances in Pork Production 15:245251.

Bee. G., G. Guex and W. Herzog. 2004. Free-range rearing of pigs during the winter: Adaptations in muscle fiber characteristics and effects on adipose tissue composition and meat quality traits. J. Anim. Sci. 82:1206-1218.

Brewer, M. S., J. Jensen, A. A. Sosnicki, B. Fields, E. Wilson and F. K. McKeith. 2002. The effect of pig genetics on palatability, color and physical characteristics of fresh pork loin chops. Meat Sci. 61:249-256.

Edwards, D. B., R. O. Bates and W. N. Osburn. 2003. Evaluation of Duroc- vs. Pietrain-sired pigs for carcass and meat quality measures. J. Anim. Sci. 81:1895-1899. 
Faucitano, L., P. Huff, F. Teuscher, C. Gariepy and J. Wegner. 2005. Application of computer image analysis to measure porkmarbling characteristics. Meat Sci. 69:537-543.

Gegner, L. 2001. Considerations in organic hog production. ATTRA's Organic Matters Series.

Gentry, J. G., J. J. McGlone, J. R. Blanton, Jr. and M. F. Miller 2002. Alternative housing systems for pigs: Influences on growth, composition, and pork quality. J. Anim. Sci. 80:17811790.

Hiner, R. L., J. W. Thornton and R. H. Alsmeyer. 1965. Palatability and quantity of pork as influenced by breed and fatness. J. Food Sci. 30:550-555.

Honeyman, M. S. 2005. Extensive bedded indoor and outdoor pig production systems in USA: current trends and effects on animal care and product quality. Livest. Prod. Sci. 64:15-24.

Honeyman, M. S. and J. D. Harmon. 2003. Performance of finishing pigs in hoop structures and confinement during winter and summer. J. Anim. Sci. 81:1663-1670.

Judge, M. D., V. R. Cahill, L. E. Kunkle and W. H. Bruner. 1959. Pork quality. I. Influences of some factors on pork muscle characteristics. J. Anim. Sci. 18:448-452.

Kleinbeck, S. N. and J. J. McGlone. 1999. Intensive indoor versus outdoor swine production systems: Genotype and supplemental iron effects on blood hemoglobin and selected immune measures in young pigs. J. Anim. Sci. 77:2384-2390.

Lammers, P. J., D. R. Stender and M. S. Honeyman. 2007. Niche pork production - Pork quality. Iowa State University.

Lebret, B., M. C. Meunier-Salaün, A. Foury, P. Mormède, E. Dransfield and J. Y. Dourmad. 2006. Influence of rearing conditions on performance, behavioral, and physiological responses of pigs to preslaughter handling, carcass traits, and meat quality. J. Anim. Sci. 84:2436-2447.

Lo, L. L., D. G. McLaren, F. K. McKeith, R. L. Fernando and J. Novakofski. 1992. Genetic analyses of growth, real-time ultrasound, carcass, and pork quality traits in Duroc and Landrace pigs: I. Breed effects. J. Anim. Sci. 70:2373-2386.
McPhee, H. C. 1931. Swine inbreeding at the United States Department of Agriculture - A Progress Report. J. Anim. Sci. 1:131-134.

Morlein, D., G. Link, C. Werner and M. Wicke. 2007. Suitability of three commercially produced pig breeds in Germany for a meat quality program with emphasis on driploss and eating quality. Meat Sci. 77:504-511.

National Pork Producers Council (NPPC). 2000. Pork Composition and Quality Assessment Procedures. E.P. Berg, ed. Des Moines, IA, USA.

Ngapo, T. M., E. Dransfield, J. F. Martin, M. Magnusson, L. Bredahl and G. R. Nute. 2003. Consumer perceptions: Pork and pig production. Insights from France, England, Sweden, and Denmark. Meat Sci. 66:125-134.

Shackelford, S. D., T. L. Wheeler and M. Koohmaraie. 2004. Technical note: Use of belt grill cookery and slice shear force for assessment of pork longissimus tenderness. J. Anim. Sci. $82: 238-241$

Skelley, G. C. and D. L. Handlin. 1971. Pork acceptability as influenced by breed, sex, carcass measurements and cutability. J. Anim. Sci. 32:239-244.

Suzuki, K., T. Shibata, H. Kadowaki, H. Abe and T. Toyoshima. 2003. Meat quality comparison of Berkshire, Duroc and crossbred pigs sired by Berkshire and Duroc. Meat Sci. 64:3542.

Thornton, K. 1990. Outdoor pig production. Farming Press, Ipswich, UK.

Winters, L. M., R. E. Comstock and D. L. Dailey. 1943. The development of an inbred line of swine (Minn. No. 1) from a crossbred foundation. J. Anim. Sci. 2:129-137.

Wood, J. D., S. N. Brown, G. R. Nute, F. M. Whittington, A. M. Perry, S. P. Johnson and M. Enser. 1996. Effects of breed, feed level and conditioning time on the tenderness of pork. Meat Sci. 44:105-112.

Yiridoe, E. K., S. Bonti-Ankomah and R. C. Martin. 2005. Comparison of consumer perceptions and preference toward organic versus conventionally produced foods: A review and update of the literature. Renew. Agric. Food Syst. 20:193-205. 